\title{
PENGOLAHAN DAUN KELOR DI DESA SIGAR PENJALIN KECAMATAN TANJUNG KABUPATEN LOMBOK UTARA
}

\author{
Hary Kurniawan ${ }^{1 *}$, Sukmawaty ${ }^{1}$, Ansar $^{1}$, \\ Rahmat Sabani ${ }^{1}$, Murad ${ }^{1}$, Kurniawan Yuniarto ${ }^{1}$, Fakhrul Irfan Khalii ${ }^{1}$ \\ ${ }^{1}$ Program Studi Teknik Pertanian, Fakultas Teknologi Pangan dan Agroindustri \\ Universitas Mataram \\ *Korespondensi: harykurniawan@unram.ac.id
}

Diterima 4 Januari 2020 / Disetujui 25 Februari 2020

\begin{abstract}
ABSTRAK
Tanaman kelor merupakan salah satu tanaman yang memiliki manfaat tidak hanya bagi kesehatan, namun juga memiliki nilai ekonomi. Seluruh bagian tanaman kelor mulai daun, kulit batang, buah dan bijinya bermanfaat bagi kesehatan. Tanaman ini dapat diolah menjadi berbagai obat herbal hingga bahan baku produk perawatan kulit. Tanaman kelor dapat tumbuh baik di daerah tropis, seperti halnya di Lombok, Nusa Tenggara Utara. Salah satu daerah yang banyak ditumbuhi tanaman kelor yaitu di Dusun Rongsot Timur, Desa Sigar Penjalin, Kecamatan Tanjung, Kabupaten Lombok Utara. Kelor diketahui memiliki banyak khasiat bagi kesehatan karena mengandung kandungan protein, kalsium, zat besi, vitamin $\mathrm{A}$ dan flavonoid. Namun sayangnya pemanfaatan tanaman kelor masih sebatas sebagai olahan sayur dan belum menjadi produk olahan yang menarik, berdaya saing dan bernilai ekonomi tinggi, dikarenakan masih terbatasnya informasi dan wawasan mitra mengenai pengolahan kelor. Tujuan dari pengabdian ini yaitu memberikan penyuluhan kepada mitra yang berada di Dusun Rosok, Desa Sigar Penjalin, Kecamatan Pemenang Barat, Kabupaten Lombok Utara mengenai pengolahan kelor. Metode yang dilakukan dalam kegiatan ini yaitu Fokus Group Discussion (FGD). Berdasarkan hasil kegiatan yang telah dialakukan diperoleh bahwa mitra belum mengenal manfaat, khasiat dan cara pengolahan tanaman kelor. Selain itu warga belum mengetahui berbagai produk olahan kelor. Namun setelah mengikuti kegiatan ini, mitra dapat mengetahui dengan baik manfaat, khasiat serta berbagai produk olahan kelor yang memiliki nilai ekonomi yang tinggi. Selain itu, keterampilan mitra pun meningkat setelah melakukan praktek langsung pengolahan daun kelor kering menjadi bubuk kelor.
\end{abstract}

Kata kunci: bubuk kelor, kelor, khasiat, produk olahan 


\section{PENDAHULUAN}

Tanaman Kelor (Moringa oleifera) merupakan tanaman yang memiliki berbagai manfaat baik secara ekonomis maupun kesehatan. Tanaman kelor merupakan jenis tanaman berkayu yang tumbuh baik di daerah tropis seperti di Indonesia, mampu tumbuh hingga ketinggian 7 - 12 meter dan tumbuh subur mulai dari dataran rendah sampai ketinggian $700 \mathrm{~m}$ di atas permukaan laut. Selain itu tanaman kelor juga mudah dibiakkan karena tidak memerlukan perawatan yang intensif dan memiliki toleransi kekeringan yang tinggi (Isnan \& Nurhaedah, 2017; Aminah dkk., 2015).

Tanaman kelor memiliki ciri-ciri batangnya berkayu, tegak, berwarna putih kotor, kulit tipis, dan permukaannya kasar. Pohon kelor banyak ditanam sebagai tapal batas atau pagar di halaman rumah atau ladang. Manfaat dan bernilai ekonomi membuat banyak yang melirik untuk membudidayakan tanaman ini mengingat bagian tanaman ini mulai dari daun, kulit batang, buah, dan bijinya memiliki manfaat yang luar biasa. Sehingga beberapa julukan disematkan untuk tanaman kelor, diantaranya The Miracle Tree, Tree for Life, dan Amazing Tree (Isnan \& Nurhaedah, 2017;

Tanaman kelor dapat tumbuh baik di daerah tropis, seperti halnya di Lombok, NTB. Tanaman berdaun hijau dengan bentuk daun bulat kecil ini bukan tanaman asing bagi masyarakat Lombok. Kelor biasa dikonsumsi warga dalam bentuk sayur yang disebut kandoq kelaq kelor atau sayur masak kelor. Salah satu wilayah yang banyak ditumbuhi tanaman kelor adalah Dusun Rongsot Timur, Desa Sigar Penjalin, Kecamatan Tanjung, Kabupaten Lombok Utara.

Kelor memiliki berbagai manfaat misalnya dapat digunakan untuk pencegahan penyakit, minyak gosok, pupuk alami, tanaman kontrol kondisi erosi, purifikasi air, bahan pembuatan kosmetik, cat tekstil, insektisida, fungisida, pewarna biru, bahan pembuatan benang, penahan angin, meningkatkan produksi madu, bahan makanan, bahan pakan ternak, serta biogas (Wahyuni dan Masyitoh, 2017).

$$
\text { Dilansir dari halaman }
$$

www.suarantb.com, khasiat kelor yang teruji dalam bidang kesehatan seperti mengandung antioksidan dan senyawa antiinflamasi. Daun kelor memiliki kandungan tinggi akan senyawa anti penuaan, yang didalamnya terdapat polifenol, vitamin C, beta-karoten, quercetin dan asam klorogenik, yang bisa meringankan bahaya dari penyakit kronis seperti diabetes, hipertensi dan penyakit mata yang diderita manula. Selain itu manfaat lain dari kelor yaitu menstabilkan hormon dan memperlambat efek penuaan, membantu meningkatkan kesehatan pencernaan, membantu melawan diabetes, melindungi dan menutrisi kulit. Selain itu kelor juga kaya akan antioksidan dan senyawa yang meningkatkan kesehatan kelenjar tiroid yang bermanfaat dalam menjaga kestabilan energi dalam tubuh dan melawan kelelahan, depresi, libido rendah, suasana 
hati tak stabil dan insomnia. Duryatmo dkk. (2011) melaporkan bahwa kelor mujarab mengatasi beragam penyakit lain seperti hepatitis, hiperlipidemia alias kolesterol tinggi, dan jantung.

Daun kelor juga saat ini telah diolah menjadi teh kelor. Manfaat teh kelor adalah mencegah dan mengobati hipertensi, diabetes, sakit jantung, meningkatkan fungsi ereksi, memperbaiki dan mengobati fungsi hati dan pencernaan. Selain itu, mencegah dan mengobati kanker, reumatik dan asam urat serta membakar kolesterol jahat. Sementara biji kelor juga dapat diolah menjadi minyak kelor yang banyak digunakan dalam industri kosmetik.

Kelor dapat dijadikan salah satu komoditi andalan untuk dapat dikembangkan secara lebih baik. Peluang untuk berinvestasi dalam bidang ini juga cukup terbuka lebar karena sektor ini belum dimanfaatkan secara maksimal. Terbukti jika tanaman ini memiliki nilai ekonomis serta diminati oleh mancanegara untuk bidang kesehatan dan juga dapat berguna untuk bahan dasar obat-obatan.

Tujuan dari kegiatan ini adalah meningkatkan wawasan dan pengetahuan mitra mengenai tanaman kelor serta manfaatnya, serta meningkatkan pengetahuan mitra mengenai pengolahan dan berbagai produk olahan berbasis kelor.

\section{METODE KEGIATAN}

Kegiatan pengabdian pada masyarakat ini berupa sosialisasi mengenai manfaat serta pengolahan tanaman kelor. Metode pelaksanaan yaitu melalui Focus
Group Discussion (FGD). Adapun tahapan pelaksanaan kegiatan meliputi melakukan koordinasi dengan kepala dusun mengenai rencana kegiatan yang akan dilaknsakan, (2) penetapan partisipan yang dalam hal ini adalah warga di Dusun Rongsot Timur, Desa Sigar Penjalin, Kecamatan Tanjung, Kabupaten Lombok Utara yang sejak lama telah mengenal tanaman kelor, (3) penyuluhan tentang manfaat tanaman kelor terutama khasiatnya bagi kesehatan, serta pengolahan kelor menjadi berbagai produkproduk yang menarik, berdaya saing dan bernilai ekonomi tinggi serta, (4) pelatihan pengolahan daun kelor menjadi kelor bubuk, dan (5) diskusi yang dilakukan oleh tim pelaksana dan mitra tentang masalah dan kendala yang dihadapi peserta saat pelaksanaan kegiatan berlangsung. Sementara itu evalusi kegiatan ini dilakukan secara langsung pada saat kegiatan berlangsung. Tahap evaluasi dilakukan setelah penyampaian materi. Prosedur evaluasi meliputi kemampuan penguasaan materi dan tanggapan terhadap materi yang telah diberikan. Kedua kriteria tersebut diamati dengan keaktifan peserta dalam bertanya dan menanggapi materi yang diberikan, keaktifan peserta selama sosialisasi. Selain itu, kehadiran peserta dalam setiap sesi sosialisasi juga menjadi parameter tingkat antusiasme peserta terhadap kegiatan sosialisasi yang dilakukan.

HASIL DAN PEMBAHASAN 


\section{Pertemuan awal}

Tahap awal yang dilakukan yaitu pertemuan awal dengan kepala Dusun Rongsot Timur, yaitu Bapak Sukri. Tujuan dari pertemuan awal ini adalah untuk berkoordinasi dan mensosialisasikan rencana kegiatan yang akan dilakukan seperti ditunjukkan pada Gambar 1. Hasil dari pertemuan ini yaitu masyarakat di Dusun Rongsot Timur yang diwakili oleh Kepala Dusun menyambut baik rencana kegiatan yang akan dilakukan oleh tim. Baik tim maupun kepala dusun telah menyepakati rencana kegiatan pengabdian kepada masyarakat dan kepala dusun siap membantu mensosialisaikan kegiatan tersebut kepada warga.

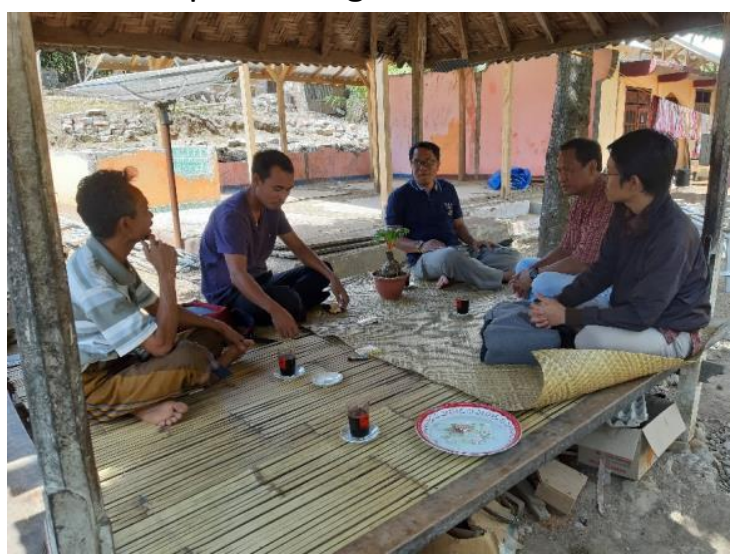

Gambar 1. Pertemuan awal dengan mitra

\subsection{Persiapan pelaksanaan kegiatan}

Berbagai persiapan dilakukan untuk merealisasikan kegiatan ini diantaranya penyusunan materi berupa power point, pembuatan kuisioner, pembuatan leaflet, dan pembuatan spanduk. Agar tujuan kegiatan dapat tercapai dengan optimal, dilakukan pembelian produk olahan kelor berupa teh kelor, bubuk kelor, masker kelor dan kapsul kelor sebagai contoh produk olahan yang akan ditunjukkan kepada mitra seperti ditunjukkan pada Gambar 2. Mitra juga akan dilatih mengolah daun kelor segar menjadi daun kelor kering yang selanjutnya diolah menjadi bubuk kelor, oleh karena itu dipersiapkan daun kelor kering seperti yang ditunjukkan pada Gambar 3 dan blender sebagai alat penunjang.

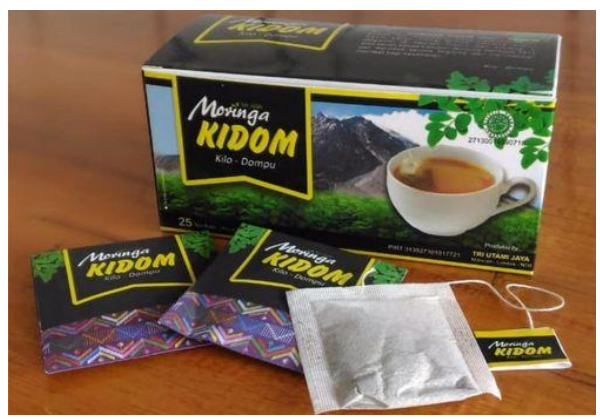

(a)

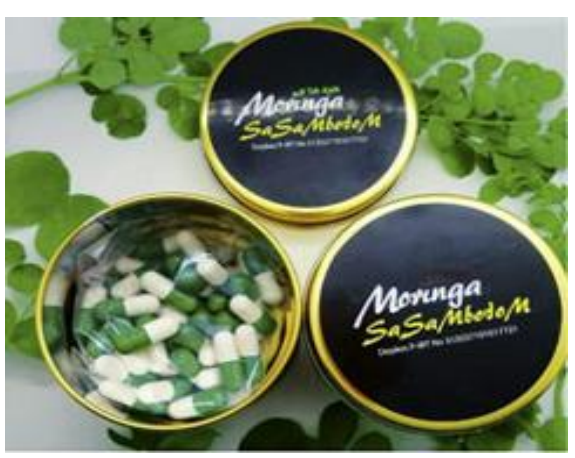

(b) 


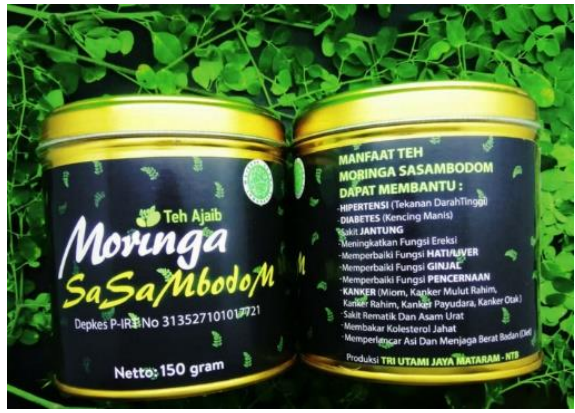

(c)



(d)

Gambar 2. Produk olahan dari kelor: (a) Teh celup kelor; (b) Kapsul kelor; (c) (c) Bubuk kelor; (d) Masker kelor

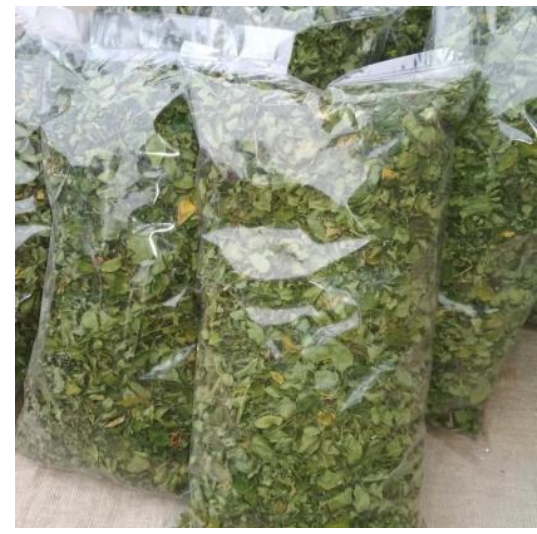

Gambar 3. Daun kelor kering

\section{Pelaksanaan Kegiatan}

Kegiatan pengabdian kepada masyarakat ini dilaksanakan pada hari Rabu, 21 Agustus 2019 bertempat di Dusun Rongsot Timur, Desa Sigar Penjalin,
Kecamatan Tanjung, Kabupaten Lombok Utara tepatnya di Puskedes. Kegiatan ini diawalii dengan sambutan oleh Bapak Sukri selaku Kepala Dusun Rongsot Timur. Usai memberikan sambutan, peserta diminta mengisi kuisioner sebelum diberikan materi seperti ditunjukkan pada Gambar 4. Pengisian kuisioner ini bertujuan untuk megetahui sejauh mana pemahaman warga mengenai pemanfaatan kelor yang selama ini telah dilakukan. Contoh kuisioner yang diisi oleh salah satu peserta disajikan pada Gambar 5.

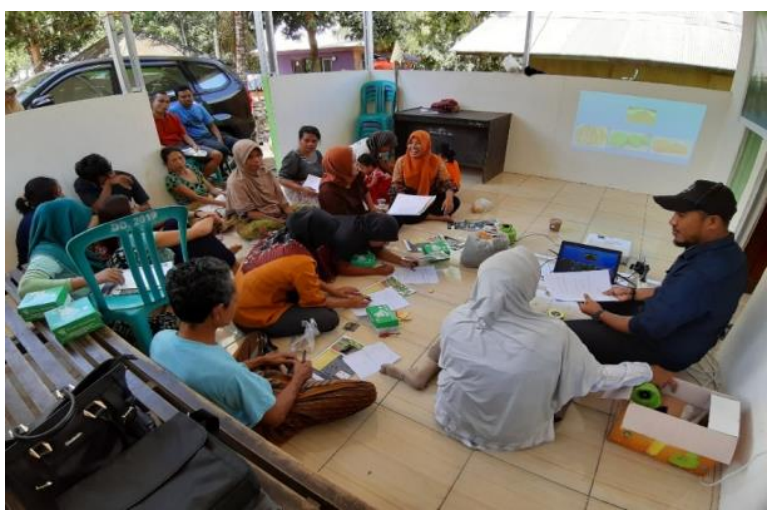

Gambar 4. Pengisian kuisioner sebelum pemberian materi

Setelah kuisioner diisi oleh peserta, kegiatan dilanjutkan dengan penyajian materi yang disampaikan oleh tim seperti ditunjukkan pada Gambar 6. Materi disampaikan melalui diskusi dengan bantuan tayangan power point. Pada sesi ini, peserta juga diberikan leaflet yang berisi tentang sekilas tanaman kelor, kandungan nutrisi serta khasiatnya bagi tubuh. Pada sesi penyampaian materi, peserta diberikan penjelasan mengenai sekilas tanaman kelor berupa fakta-fakta tentang tanaman kelor seperti kandungan nutrisnya maupun 
berbagai manfaat dan khasiat yang diperoleh tanaman kelor, khususnya daun kelor. Selain itu, peserta juga ditunjukkan berbagai produk olahan dari kelor seperti teh kelor, kapsul kelor, bubuk kelor dan masker kelor.

Setelah penyampaian materi mengenai pemanfaatan tanaman kelor, peserta diajak untuk praktek mengolah daun kelor kering menjadi kelor bubuk seperti Gambar 7. Peserta tidak hanya diberikan penjelasan mengenai pengolahan kelor, tetapi juga diberikan kesempatan untuk praktek mengolah daun kelor kering mejadi bubuk kelor. Salah satu peserta dapat mempraktekkan dengan baik cara mengolah daun kelor menjadi kelor bubuk menggunakan blender yang telah disediakan.

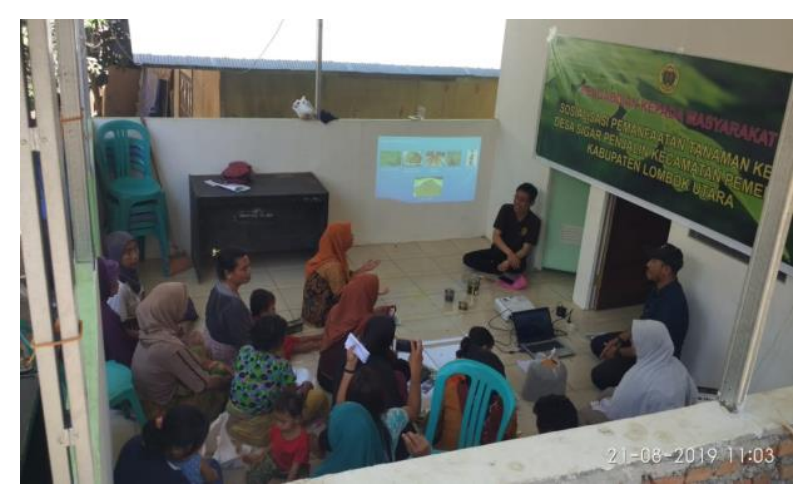

Gambar 6. Penyampaian materi tentang pemanfaatan kelor
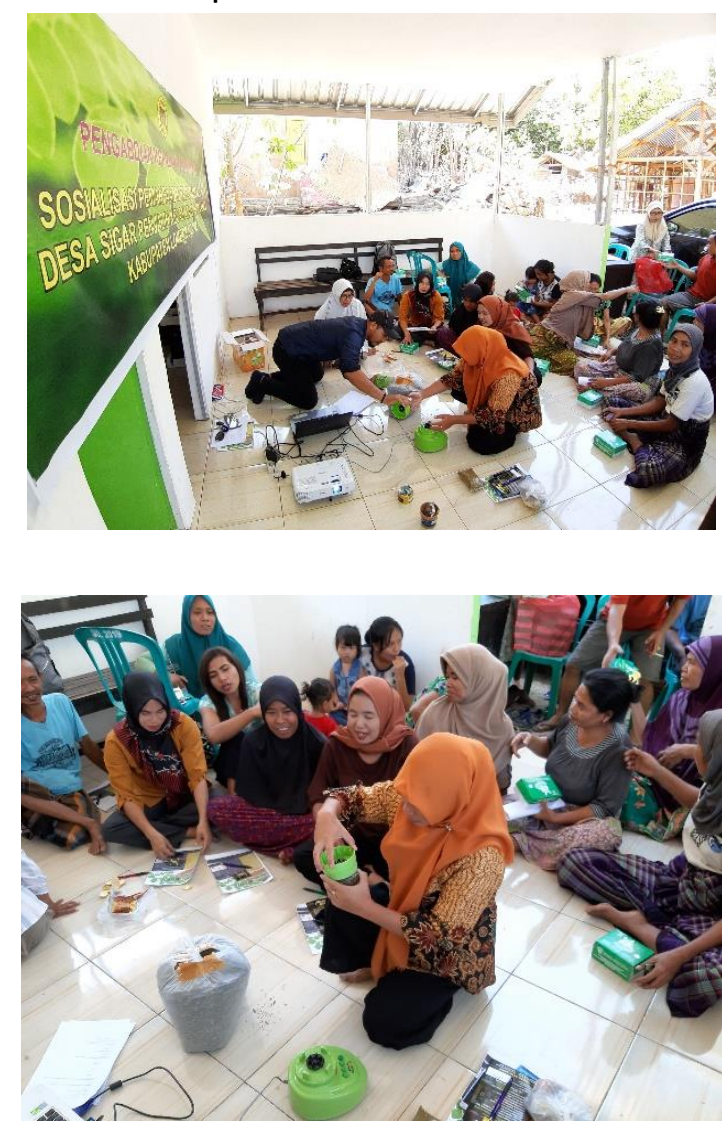

Gambar 7. Praktek pembuatan kelor bubuk

Usai pemberian materi, dilakukan sesi diskusi dan tanya jawab. Pada sesi ini peserta cukup antusias menyampaikan berbagai pertanyaan terkait pemanfaatan dan pengolahan kelor kepada tim. Peserta juga tertarik dengan peluang usaha kelor seperti usaha daun kelor kering, kelor 
bubuk serta usaha produk olahan kelor seperti kue bawang (stick bawang) kelor. Setelah penyampaian materi yang disertai sesi diskusi maupun tanya jawab, peserta kembali diminta untuk mengisi kuisioner seperti ditunjukkan pada gambar 8. Kuisioner tersebut ditujukan untuk mengetahui apakah kegiatan sosialisasi dan pengabidan kali ini mampu menambah wawasan dan pengetahuan mitra tentang khasiat dan manfaat tanaman kelor serta berbagai produk turunan dari kelor seperti yang ditunjukkan pada Gambar 9.

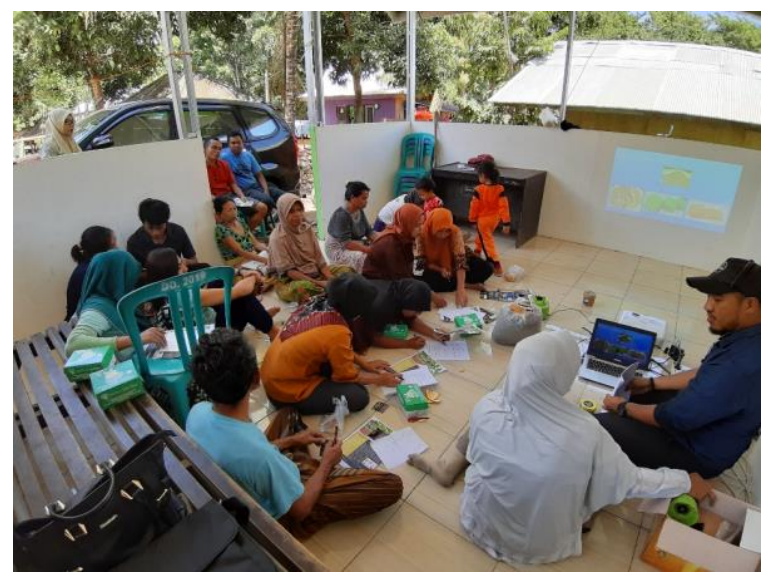

Gambar 8. Pengisian kuisioner setelah penyampaian materi

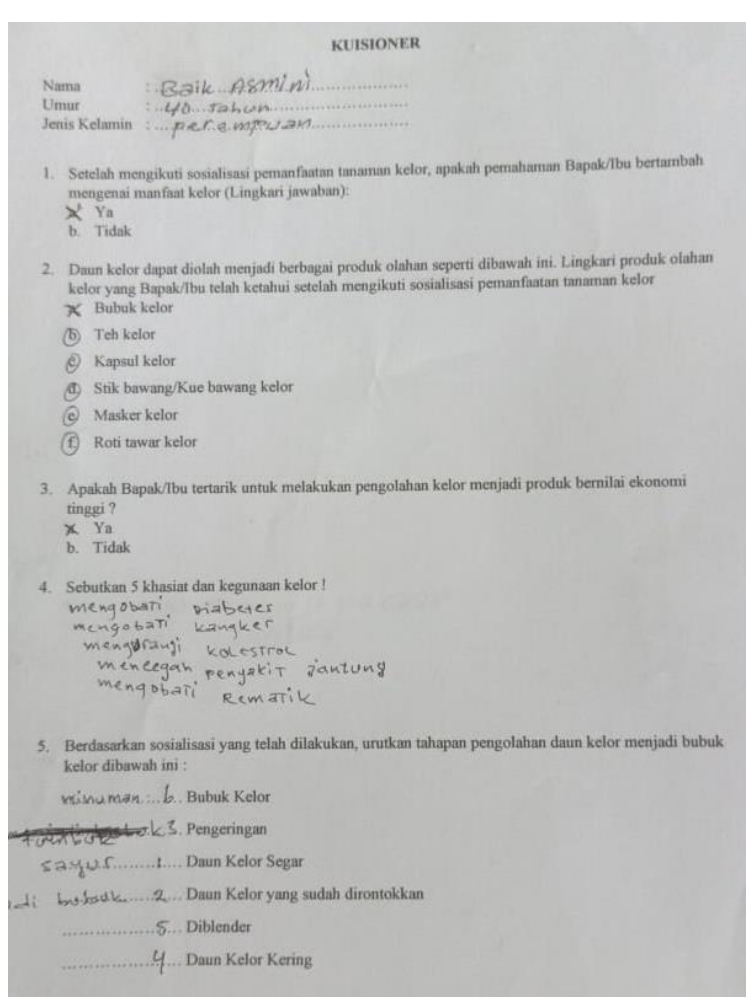

Gambar 9. Kuisioner setelah penyampaian materi

Berdasarkan hasil kuisioner yang telah diisi oleh peserta menunjukkan bahwa kegiatan sosialisasi pemanfaatan sekaligus pelatihan pengolahan daun kelor kering menjadi kelor bubuk telah menambah pengalaman, wawasan dan keterampilan warga. Sebagian besar warga tertarik untuk mengolah kelor menjadi berbagai produk yang bernilai ekonomi tinggi. Selain itu, peserta juga dapat menyebutkan berbagai khasiat dar kelor setelah mengikuti rangkaian kegiatan ini dan dapat mengurutkan tahapan pengolahan daun kelor segar menjadi daun kelor kering dan bubuk kelor.

\section{Tantangan Mitra}


Berdasarkan hasil kegiatan yang telah dilakukan, menunjukan bahwa pemahaman mitra mengenai berbagai khasiat dan manfaat dari tanaman kelor khususnya daun kelor meningkat. Selain itu keterampilan mitra juga meningkat melalui praktek pengolahan daun kelor kering menjadi bubuk kelor. Namun demikian, beberapa tantangan yang dihadapi oleh peserta diantaranya adalah cara pengolahan kelor yang baik agar menjadi berbagai produk olahan yang tidak hanya bernilai ekonomi tinggi, tetapi juga aman dikonsumsi. Tantangan lainnya yaitu perlu adanya sentuhan teknologi dalam pengolahan dan pengemasan produk olahan kelor dan strategi pemasaran produk olahan kelor agar jangkauan pemasarannya luas dan mampu menjadi produk lokal unggulan di Dusun Rongsot Timur. Oleh karena itu diharapkan melalui serangkaian kegiatan yang telah dilaksanakan ini, setidaknya warga tertarik untuk mengolah daun kelor menjadi daun kelor kering yang saat ini telah memiliki pasar sendiri dengan harga berkisar Rp. 20.000 per kg daun kering. Hal ini secara tidak langsung akan meningkatkan pendapatan warga setempat mengingat kodisi warga setempat yang masih belum sepenuhnya bangkit pasca gembar Lombok yang terjadi pada Agustus 2018.

\section{KESIMPULAN DAN SARAN}

\section{Kesimpulan}

Berdasarkan hasil kegiatan yang telah dialakukan diperoleh bahwa mitra belum mengenal manfaat, khasiat dan cara pengolahan tanaman kelor. Selain itu warga belum mengetahui berbagai produk olahan kelor. Namun selah mengikuti kegiatan ini, mitra dapat mengetahui dengan baik manfaat, khasiat serta berbagai produk olahan kelor yang memiliki nilai ekonomi yang tinggi. Selain itu, keterampilan mitra pun meningkat setelah melakukan praktek langsung pengolahan daun kelor kering menjadi bubuk kelor.

\section{Saran}

Perlu dilakukan tindak lanjut berupa pelatihan pengolahan kelor menjadi berbagai produk-produk bernilai ekonomi, pelatihan cara pengolaha yang baik, pelatihan teknik pengemasan produk serta pelatihan strategi pemasaran produk agar memperluas jangkauan pemasaran.

\section{UCAPAN TERIMA KASIH}

Penulis mengucapkan terima kasih kepada LPPM Universitas Mataram yang telah memberi dukungan finansial terhadap pengabdian ini.

\section{DAFTAR PUSTAKA}

Aminah, S., Ramdhan, T., Yanis, M. 2015. Kandungan Nutrisi dan Sifat Fungsional Tanaman Kelor (Moringan oleifera). Buletin Pertanian Perkotaan. Vol. 5 (2): 35 $-44$

Duryatmo, S., Titisasri, A., Wiguna, I., Karina, P., Susanti, T. 2011. Kelor sejuta khasiat. Artikel. http://www.trubu-sonline.co.id. Di akses 16 September 2019. 
Isnan, W., M., Nurhaedah. 2017. Ragam Manfaat Tanaman Kelor (Moringa Oleifera Lamk.) Bagi Masyarakat. Info Teknis EBONI. Vol. 14 (1): 63 75

Kumala, N., Masfutatun, R., Emilia Devi D. 2016. Potensi Ekstrak Daun Kelor (Moringa Oleifera) Sebagai Hepatoprotektor Pada Tikus Putih (Rattus Novergicus) yang Diinduksi Parasetamol Dosis Toksis. Jurnal “Ilmiah Kedokteran" Vol. 5 (1): 58 66

Sandi, A., Sangadji, M.. N., Samudin, S. 2019. Morfologi dan Anatomi Tanaman Kelor (Moringa oleifera I.) Pada Berbagai Ketinggian Tempat Tumbuh. e-J. Agrotekbis 7 (1): $28-36$.

SuaraNTB.com. 12 November 2016. Sejuta Khasiat Tanaman Kelor..https:// webcache.googleusercontent.com/s earch?q=cache:5zmxYXHDxu4J:https ://www.suarantb.com/gaya.hidup/k esehatan/2016/11/14320/sejuta.kha siat.tanaman.kelor/+\&cd=1\&hl=id\&c $\mathrm{t}=\mathrm{clnk} \& \mathrm{gl}=\mathrm{id}$. Diakses 14 Februari 2019.

Wahyuni, Ariana L., Masyitoh, Farahdita D. 2017. Profil Protein Daun Moringa Oleifera Mataram Dan Madura Dengan Metode Sds-Page. Seminar Nasional dan Gelar Produk 2017. UMM. 